\title{
Niche segregation amongst sympatric species at exposed sandy shores with contrasting wrack availabilities illustrated by stable isotopic analysis
}

\author{
Filipa Bessa*, Alexandra Baeta, João Carlos Marques \\ IMAR-CMA Marine and Environmental Research Centre, Department of Life Sciences, University of Coimbra, 3004-517 Coimbra, Portugal
}

\section{A R T I C L E I N F O}

\section{Article history:}

Received 9 August 2013

Accepted 22 September 2013

\section{Keywords:}

Sandy beach

Primary consumers

Peracarid crustaceans

Diet

Stable isotopes

Niche segregation

\begin{abstract}
A B S T R A C T
Wrack supplies (macroalgae, seagrasses and carrion) are a common feature of sandy beaches worldwide. These allochthonous inputs are a potential high-quality food subsidy for beach fauna, but little is known about the feeding ecology and niche segregation strategies of these species in beaches with limited wrack availabilities. We used stable isotopic ratios of nitrogen and carbon to examine the diets and niche segregation among three sympatric crustaceans, the amphipods Talitrus saltator and Talorchestia brito, and the isopod Tylos europaeus, in two temperate beaches, Cabedelo and Quiaios, on the Portuguese Atlantic coast, with contrasting wrack availabilities, over winter and summer. In the beach with limited wrack (Quiaios), consumers showed significantly different interspecific and temporal isotopic signatures, suggesting a distinct foraging habitat and niche differentiation. Mixing models outputs (SIAR) revealed in this case a seasonal shift in the diet of consumers from terrestrial sources in winter towards marinebased sources (phytoplankton) in the summer. In contrast, at Cabedelo, consumers showed clear overlap in isotopic signatures, with similar contributions of the available wrack to their diets. As a whole, an opportunistic and generalist feeding behaviour was described for these species, namely for $T$. saltator. Isotopic profiles support the occurrence of spatial overlap during summer but different foraging strategies of the three species in these beaches during winter. Our results show that on temperate beaches with ephemeral wrack supplies, consumers might need to adopt different foraging strategies and niche segregation for their subsistence, and additionally illustrate the viability of using stable isotopes to capture subtle changes in trophic niches.
\end{abstract}

(c) 2013 Elsevier Ltd. All rights reserved.

\section{Introduction}

Exposed sandy beaches form a highly dynamic interface between marine and terrestrial ecosystems that are generally characterised by little in situ primary productivity (McLachlan and Brown, 2006). These transitional habitats are mainly subsidised by allochthonous inputs of organic material from the coastal ocean (Colombini et al., 2003; Dugan et al., 2003; Griffiths et al., 1983), that vary from phytoplankton to beach-cast wrack, consisting of seagrasses, macroalgae, and carrion (Griffiths et al., 1983; Rossi and Underwood, 2002). This marine organic material is transported onshore by physical forces (e.g. wind, waves and currents), and accumulated in large volumes in the surf zones, being an important food resource to beach consumers-a trophic subsidy (sensu Polis et al., 1997).

\footnotetext{
* Corresponding author. Tel.: +351239 836386.

E-mail address: afbessa@uc.pt (F. Bessa).
}

The allochthonous inputs of nutrients for beach fauna are ubiquitous on exposed sandy shores worldwide and the pulse subsidies have multiple effects on food web dynamics on coastal areas (Heck et al., 2008; McLachlan and Brown, 2006).

One of the most important ecological roles of the invertebrates (as primary consumers) inhabiting sandy shores is the fragmentation and decomposition of beach-cast wrack as sources of energy and nutrients (organic matter) (Catenazzi and Donnelly, 2007; Colombini et al., 2003; Lastra et al., 2008; Salathé and Riera, 2012). In addition, the availability of wrack would influence the structure of these primary consumers (mainly crustaceans), which in turn supports the growth of consumers in higher trophic levels (e.g. shorebirds) resulting in the transfer of energy across coastal ecotones (review in Colombini et al., 2003).

The wrack deposits exported from the surrounding ecosystems such as rocky shores or seagrass beds are highly variable in space and time, and are also dependent on the beach type and the nearshore hydrodynamics (Gómez et al., 2013; Gonçalves and Marques, 2011; Orr et al., 2005). Beach fauna, commonly dominated by air-breathing scavenging crustaceans, face many challenges 
locating food resources and have likely evolved behavioural and physiological adaptations to live in this nutrient-limited environment (McLachlan and Brown, 2006). In general, most of these scavengers (namely talitrid amphipods and isopods) live buried between the drift line and the base of the foredunes during the day, emerging at night to feed and move across the shoreline (Scapini et al., 1997). Although these species have generally been regarded as essentially herbivorous, an opportunistic behaviour (detritivorous) has been described for these taxa (Adin and Riera, 2003; Porri et al., 2011).

The vertical distribution of available resources on sandy shores has been identified as the main factor driving population abundance and zonation of co-occurring mobile fauna (Ince et al., 2007; Jaramillo et al., 2006; MacMillan and Quijón, 2012; Rodil et al., 2008). Therefore, sympatric crustaceans need to partition both in situ and allochthonous marine resources to avoid direct competition for food resources on these systems (Huxel et al., 2002). Competition may, however, be lowered if species partition their niches by separating their surface activity (i.e. feeding in different zones), being active during different times of the day, or a combination of both spatial and temporal foraging strategies. In fact, differences in space and time partitioning of locomotor activities over the beach surface have been reported for several species of these brooding crustaceans (e.g. Jaramillo et al., 2003; Lastra et al., 2010; Scapini et al., 1992). Understanding foraging strategies of consumers inhabiting the same system is essential to understand their trophic relationships and ecological roles.

On exposed sandy beaches of temperate region, the abundant talitrid amphipods and oniscoidean isopods, are considered important wrack-deposit consumers (e.g. Gonçalves and Marques, 2011; Lastra et al., 2010; Rossi et al., 2010). Several studies highlighted the influence of beach wrack on the shore face as food resources for primary consumers (e.g. Crawley et al., 2009; Heck et al., 2008; Hyndes and Lavery, 2005; Rossi et al., 2010) and its role as an habitat for abundant beach invertebrates (e.g. Colombini et al., 2000; Duong and Fairweather, 2010; MacMillan and Quijón, 2012; Olabarria et al., 2007). The dietary wrack preferences of particular taxa (mainly amphipods) were also extensively studied, and while some studies showed similarly strong preferences for the brown algae (Adin and Riera, 2003; Crawley and Hyndes, 2007; Duarte et al., 2010; Olabarria et al., 2009), others showed that they are indiscriminate feeders (McLeod et al., 2013) and even not related with specific wrack species (Colombini et al., 2009; Porri et al., 2011).

In recent years, food web ecologists have been taken advantage of natural variation in isotope composition of food items to reconstruct the diets of several species (Boecklen et al., 2011; Peterson and Fry, 1987; Post, 2002). Stable isotopes ratios of carbon and nitrogen have been proved to be able to discriminate among various primary producers that did support the food web in several coastal regions (Baeta et al., 2009; Bergamino et al., 2011; DeNiro and Epstein, 1978, 1980). Stable isotope analysis (SIA) is currently among the most powerful tools for the study of trophic relationships and to estimate niche segregation among species in the marine environment (Cummings et al., 2012), and its use in characterising the food web structure of macrofaunal communities or consumers diets is relatively common on sandy beaches (e.g. Bergamino et al., 2011; Colombini et al., 2011; Olabarria et al., 2009; Rossi et al., 2010). However, on sandy shores with a low contribution of wrack, where organic material is typically composed of ephemeral algal fragments and vascular dune plants detritus, the feeding ecology and the niche segregation strategies of beach consumers are poorly understood.

Exposed sandy beaches are among the most common coastal ecosystems along the Western Portuguese coast (European Atlantic coast), but beaches here differ in the wrack availabilities (Gonçalves and Marques, 2011). Some of the most conspicuous representative species of these beaches are the talitrid amphipods Talitrus saltator and Talorchestia brito, and the oniscoidean isopod Tylos europaeus, widely studied in the central coast of Portugal (Gonçalves et al., 2005, 2009, 2013; Marques et al., 2003).

The aim of the present study was to determine if there is isotopic evidence for significant niche segregation among sympatric crustaceans living on exposed sandy shores with contracting wrack availabilities. We compared therefore the temporal isotopic signatures of primary consumers and potential food sources, the diets of consumers, and the pattern of distribution along the shore at two highly dynamic beaches on the European Atlantic coast (Portugal). Finally, we examined whether our findings based on stable isotope ratio analyses agree with previous descriptions of spatial surface activity segregation for these sympatric crustaceans.

\section{Materials and methods}

\subsection{Study area}

The study was carried out on two high energetic mesotidal sandy beaches: Cabedelo $\left(40^{\circ} 07^{\prime} 32^{\prime \prime} \mathrm{N}, 8^{\circ} 51^{\prime} 49^{\prime \prime} \mathrm{W}\right)$ and Quiaios $\left(40^{\circ} 12^{\prime} 21^{\prime \prime} \mathrm{N}, 8^{\circ} 53^{\prime} 48^{\prime \prime} \mathrm{W}\right)$ beaches, located on the European Atlantic coast (central Portugal) during the winter (January) and summer (July) 2011 (Fig. 1). This area is characterised by a maritime climate with mild winters and cool summers with the minimum average temperature of the coldest month of $4.8^{\circ} \mathrm{C}$ and the maximum average of the warmest month of $24.2^{\circ} \mathrm{C}$ (Danielsen, 2008). Both beaches present a high wave exposure environment and a mesotidal regime, with a mean spring tidal range of ca. $3.5 \mathrm{~m}$ (Gonçalves et al., 2009).

The Cabedelo sandy beach have a high recreational potential since it is located in a urban area while the Quiaios beach is located further north, about $8 \mathrm{~km}$ south of the Cape Mondego and more preserved from anthropogenic disturbances. The former beach is narrow (width approximately $80 \mathrm{~m}$ ) and contains medium sediments, whereas Quiaios is wider (width approximately $100 \mathrm{~m}$ ) and consists mainly of coarse sands (for more detailed description of the area, see Gonçalves et al., 2009). Quiaios beach is backed by a welldeveloped foredune, up to $2 \mathrm{~m}$ in height, which is vegetated with the dominant dune plants: Ammophila arenaria (L.), Euphorbia paralias (L.), Elymus farctus subsp. farctus (L.) and Otanthus maritimus.

At Cabedelo beach (touristic beach), local facilities located in the vicinity of the foredunes have partially damaged it and limited the local dune plants abundance and diversity (personal observations). However, this beach received large amounts of drift wrack (mainly macroalgae) that accumulate in the surf zone coming from rocky shores near the beach, while Quiaios is clearly more limited (Gonçalves and Marques, 2011).

The predominant wrack consumers are the semiterrestrial crustaceans amphipods T. brito, T. saltator, and the isopod T. europaeus. A full characterisation of the main physical features and macrofaunal communities of both beaches is provided in Gonçalves et al. (2009, 2013) and Marques et al. (2003).

\subsection{Sampling design}

Crustaceans (T. brito, T. saltator and T. europaeus) and potential food sources: Beach wrack (Fucus sp., Ulva sp., carrion) and dune plants detritus were collected (depending on their availability) along the sea-dune axis from Quiaios and Cabedelo beaches during both wet (winter, January) and dry (summer, July) seasons. In addition, seawater was collected from the swash zone of the beach for determination of suspended particulate organic matter (POM) as a proxy of phytoplankton. 


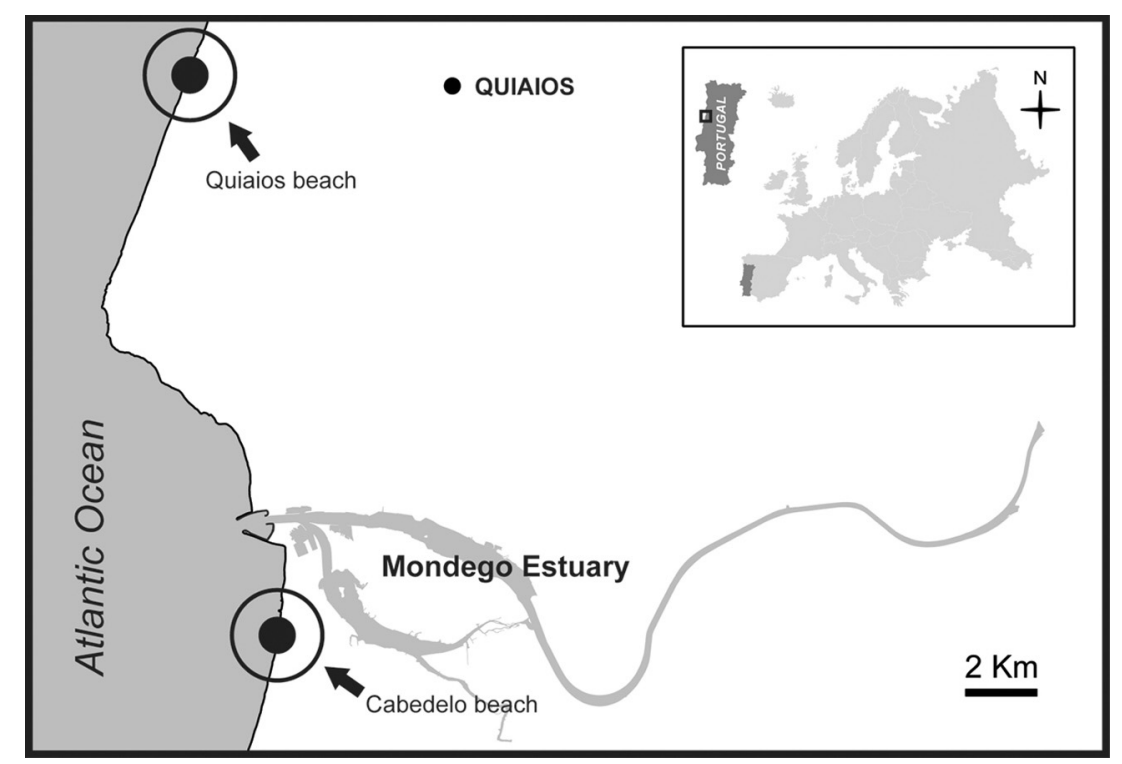

Fig. 1. Map of the study area showing the sampling beaches: Cabedelo and Quiaios, on the European Atlantic coast (Portugal).

Animals were collected by hand and were kept alive in local sand and then transported to the laboratory for stable isotopic analysis. Wrack quantity $\left(\mathrm{g} \mathrm{m}^{-2}\right)$ and the organic matter content in the sediment were determined according to the procedures described in Marques et al. (2003). A second sub-sample was taken during neap tide from each sampling season in order to assess the natural zonation pattern of the sympatric crustaceans. To reduce the risk of disturbing the animals, a distance of at least $10 \mathrm{~m}$ was kept between the samples. At each beach, samples (cores $0.05 \mathrm{~m}^{2}, 30 \mathrm{~cm}$ deep) were collected with PVC cylinders at 10 equally spaced levels along two separate transects on the sea-dune axis. Animals were sieved through a $1 \mathrm{~mm}$ mesh bags, preserved in $70 \%$ alcohol and taken to the laboratory for species identification. Simultaneous to biological sampling, water temperature $\left({ }^{\circ} \mathrm{C}\right)$ and salinity were measured in situ using a YSI (Professional plus) field probe.

\subsection{Laboratory procedures and stable isotope analysis (SIA)}

Water samples (51 of seawater per season and per beach) collected for phytoplankton (chlorophyll $a$ ) measurements were filtered through Whatman GF/F glass-fibre filters. Particulate organic matter (POM) was measured by filtering $1.5 \mathrm{l}$ of seawater collected, onto precombusted $\left(450^{\circ} \mathrm{C}, 4 \mathrm{~h}\right)$ Whatman $\mathrm{GF} / \mathrm{F}$ filters $(0.45 \mu \mathrm{m}$ pore size) with a low-pressure vacuum pump within $2 \mathrm{~h}$ of collection.

In the laboratory, animals for SIA were sorted alive and held in filtered seawater for $8 \mathrm{~h}$ to allow their stomach to clear. Subsequently, organisms were identified and separated by species. Crustaceans, beach wrack and dune plants were rinsed with Milli$Q$ water to remove potential detritus and oven dried $\left(60^{\circ} \mathrm{C}, 48 \mathrm{~h}\right)$. Once dried, samples were ground into fine powder using mortar and pestle, weighted, and loaded into tin capsules.

The carbon and nitrogen isotopic composition of the samples was determined using a Flash EA 1112 Series elemental analyser coupled on line via Finningan conflo II interface to a Thermo delta V S mass spectrometer. The carbon and nitrogen isotope ratios are expressed in delta $(\delta)$ notation, defined as the parts per thousand (\%) deviation from a standard material (PDB limestone for $\delta^{13} \mathrm{C}$ and atmospheric nitrogen for $\delta^{15} \mathrm{~N} ; \delta^{13} \mathrm{C}$ or $\delta^{15} \mathrm{~N}=\left[\left(R_{\text {sample }} / R_{\text {standard }}\right)-1\right] \times 1000$, where $R={ }^{13} \mathrm{C} /{ }^{12} \mathrm{C}$ or ${ }^{15} \mathrm{~N} /{ }^{14} \mathrm{~N}$.
Precision in the overall preparation and analysis was better than $0.2 \%$ for both $\delta^{13} \mathrm{C}$ and $\delta^{15} \mathrm{~N}$.

\subsection{Data analyses}

At both beaches and for each sampling occasion, the mean zonation (corresponding to relative abundance along the transects from the sea-line to the back of the dunes) was calculated for all individuals collected. The frequency of each species found was calculated.

To determine if isotopic signatures varied among consumers (and food sources), beaches and seasons, to account for data heteroscedasticity, we used a three-way permutational analysis of variance (PERMANOVA) (Anderson, 2001). The dependent variables $\delta^{13} \mathrm{C}$ and $\delta^{15} \mathrm{~N}$ signatures were compared independently among the fixed factors: Beach (Cabedelo and Quiaios), Seasons (winter and summer), and Species (consumers and food sources). We considered seasons as fixed factor because sampling dates were not chosen randomly from the possible dates over a year, being instead selected using the criterion that they should include the most extreme periods of the year in this region. When appropriate, a posteriori multiple comparisons were used to test for differences between/within groups for pairs of levels of factors, and Monte Carlo tests were included where insufficient unique permutations existed for meaningful tests $(<150)$. The tests were based on Euclidean distance matrices using 9999 unrestricted permutations of raw data and calculated from normalised, untransformed data. Statistical analyses were conducted using Primer v.6 and PERMANOVA (Primer-E Ltd., Plymouth, UK).

In order to obtain the relative contribution of the different food sources, we used a Bayesian stable-isotope mixing model (SIAR; Parnell et al., 2010) which allows the inclusion of isotopic signatures, elemental concentrations and fractionation together with the uncertainly of these values within the model. Although fractionation is usually accepted to be relatively constant at each trophic level, amphipods and herbivores in general may show great variability (Vander Zanden and Rasmussen, 2001). To investigate the role of wrack as food sources we applied the traditional mean trophic enrichment of $1 \%$ for $\delta^{13} \mathrm{C}$ and 3.4\% for $\delta^{15} \mathrm{~N}$ (Adin and Riera, 2003; DeNiro and Epstein, 1978, 1980; Minagawa and Wada, 1984), which also allows comparisons on similar studies based on the trophic ecology of the same or congeneric species (e.g. Adin 
Table 1

Physicochemical parameters and autotrophic variables recorded each season (winter and summer 2011) at Quiaios and Cabedelo beaches, Portugal.

\begin{tabular}{lcccccc}
\hline & \multicolumn{2}{l}{ Quiaios } & & \multicolumn{2}{l}{ Cabedelo } \\
\cline { 2 - 3 } \cline { 6 - 7 } \cline { 6 - 7 } & Winter & Summer & & Winter & Summer \\
\hline Water temperature $\left({ }^{\circ} \mathrm{C}\right)$ & 12.7 & 18 & & 12 & 18.2 \\
Salinity & 35.5 & 35 & & 33 & 34 \\
Total phytoplankton $\left(\mathrm{mg} \mathrm{Chl} a \mathrm{~m} \mathrm{~m}^{-3}\right)$ & 2.51 & 5.91 & & 1.59 & 2.68 \\
Organic matter content $(\%)$ & 0.16 & 0.34 & & 0.32 & 0.37 \\
Wrack quantity $\left(\mathrm{g} \mathrm{m}^{-2}\right)$ & 9.76 & 0.81 & & 31.06 & 15.21 \\
\hline
\end{tabular}

and Riera, 2003; Olabarria et al., 2009; Porri et al., 2011; Rossi et al., 2010). In addition, these values are known to better identify wrack species as food sources for these amphipod species than other values recently proposed in the literature (e.g. Rossi et al., 2010). Data were graphically represented using dual-isotope graphs.

The estimated proportional contributions of each source item to the diet of consumers were plotted by SIAR using 95\%, 75\% and 25\% credibility intervals (Parnell et al., 2010).

\section{Results}

\subsection{Environmental variables and food sources}

Water temperature and salinity were similar at Quiaios and Cabedelo beaches in sampling occasions (Table 1). Both beaches were organically enriched, although Cabedelo presented higher wrack quantity and more organic matter content in the sediment (Table 1), while Quiaios showed the highest concentration of chlorophyll $a$ during the warmer season (Table 1 ). The wrack quantity collected was higher during the winter at both beaches (31.06 $\mathrm{g} \mathrm{m}^{-2}$ in Cabedelo and $9.76 \mathrm{~g} \mathrm{~m}^{-2}$ in Quiaios).

\subsection{Consumers' zonation}

The distribution of sympatric crustaceans from the lower to the upper zone of the beach exhibited clear seasonal patterns of variation (Fig. 2).

During the winter at Quiaios, consumers occurred mainly in the supralittoral zone (the zone above the drift line; Fig. 2a), while at Cabedelo only $T$. saltator was limited to the supralittoral zone being the other two species found near the drift line (Fig. 2b). On the other hand, at Cabedelo, during the warmer season all consumers remained restricted to the drift line and $78 \%$ of $T$. brito individuals were found near the swash zone (about $30 \mathrm{~m}$ from the sea). An identical summery pattern was observed in Quiaios, with all crustaceans being found in the lower shore on the beach (Fig. 2a).
Table 3

Results of three-way PERMANOVA testing for differences in $\delta^{13} \mathrm{C}$ and $\delta^{15} \mathrm{~N}$ values of beach consumers (Talitrus saltator, Talorchestia brito and Tylos europaeus) and food sources (POM, dune plants, Fucus sp., Ulva sp. and carrion) between beaches (Quiaios and Cabedelo, Portugal) and seasons (winter and summer 2011).

\begin{tabular}{|c|c|c|c|c|c|c|c|}
\hline \multirow[t]{2}{*}{ Consumers } & \multicolumn{4}{|c|}{$\delta^{13} \mathrm{C}$} & \multicolumn{3}{|c|}{$\delta^{15} \mathrm{~N}$} \\
\hline & df & MS & $F$ & $P($ perm $)$ & MS & $F$ & $P($ perm $)$ \\
\hline S-Species & 2 & 12.53 & 256.63 & 0.0001 & 19.81 & 74.99 & 0.0001 \\
\hline B-Beach & 1 & 5.13 & 105.14 & 0.0001 & 33.14 & 125.56 & 0.0001 \\
\hline Se-Season & 1 & 14.06 & 287.95 & 0.0001 & 3.11 & 11.8 & 0.0012 \\
\hline $\mathrm{S} \times \mathrm{B}$ & 2 & 5.18 & 106.16 & 0.0001 & 8.81 & 33.37 & 0.0001 \\
\hline $\mathrm{S} \times \mathrm{Se}$ & 2 & 5.18 & 68.64 & 0.0001 & 1.42 & 5.42 & 0.0078 \\
\hline $\mathrm{B} \times \mathrm{Se}$ & 1 & 0.53 & 10.32 & 0.002 & 0.01 & 0.01 & 0.0069 \\
\hline $\mathrm{S} \times \mathrm{B} \times \mathrm{Se}$ & 2 & 3.11 & 63.82 & 0.0001 & 1.42 & 5.39 & 0.0079 \\
\hline Res & 60 & 0.04 & & & 0.26 & & \\
\hline Total & 71 & & & & & & \\
\hline Food & & & $\delta^{13} C$ & & & $\delta^{15} \mathrm{~N}$ & \\
\hline sources & $\mathrm{df}$ & MS & $F$ & $P($ perm $)$ & MS & $F$ & $P($ perm $)$ \\
\hline S-Species & 3 & 9.78 & 2160.5 & 0.0001 & 5.27 & 209.02 & 0.0001 \\
\hline B-Beach & 1 & 0.01 & 0.08 & 0.7799 & 0.42 & 16.612 & 0.0011 \\
\hline Se-Season & 1 & 0.08 & 17.22 & 0.0013 & 0.13 & 5.18 & 0.0372 \\
\hline $\mathrm{S} \times \mathrm{B}$ & 3 & 0.02 & 5.41 & 0.01 & 0.78 & 30.78 & 0.0001 \\
\hline $\mathrm{S} \times \mathrm{Se}$ & 3 & 0.31 & 67.85 & 0.0001 & 0.44 & 17.61 & 0.0001 \\
\hline $\mathrm{B} \times \mathrm{Se}$ & 1 & 1.35 & 298.67 & 0.0001 & 5.31 & 210.81 & 0.0001 \\
\hline $\mathrm{S} \times \mathrm{B} \times \mathrm{Se}$ & 3 & 1.19 & 88.32 & 0.0001 & 2.49 & 98.79 & 0.0001 \\
\hline Res & 18 & 0.01 & & & 0.02 & & \\
\hline Total & 33 & & & & & & \\
\hline
\end{tabular}

\subsection{Stable isotopes}

\subsubsection{Consumers}

The mean $\delta^{13} \mathrm{C}$ and $\delta^{15} \mathrm{~N}$ values obtained for the sympatric crustaceans (T. saltator, T. brito and T. europaeus) varied significantly between the beaches and seasons (Tables 2 and 3: PERMANOVA interaction for all factors $p$ (perm) <0.05). Examination of PERMANOVA interaction term (species $\times$ beach $\times$ season) showed that in both seasons all consumers from Cabedelo showed significantly higher isotope ratios than their counterparts in Quiaios (Table 2; PERMANOVA, $p$ (perm) <0.05). The only two exceptions were observed during the winter for $T$. brito $(p($ perm $)=0.7327)$, which had similar $\delta^{15} \mathrm{~N}$ values $(12.82 \pm 0.51 \%$ in Cabedelo and $12.75 \pm 0.14 \%$ in Quiaios), and for T. europaeus, which presented higher $\delta^{13} \mathrm{C}$ values at Quiaios (Table 2). $\delta^{13} \mathrm{C}$ values of all consumers were significantly depleted during winter in both beaches (PERMANOVA pairwise: $p$ (perm) <0.05), except for $T$. brito at Cabedelo which had similar values in both seasons (Table 2). In contrast, $\delta^{15} \mathrm{~N}$ values have not shown significant temporal differences for T. europaeus at Quiaios (PERMANOVA: $p$ (perm) $=0.2459$ ), and for both talitrids at Cabedelo (Table 2; PERMANOVA: T. saltator $p($ perm $)=0.5910$, . brito $p($ perm $)=0.3877)$.

There was also inter-specific significant segregation in both $\delta^{13} \mathrm{C}$ and $\delta^{15} \mathrm{~N}$ values of consumers at Quiaios during winter (Fig. 3a;

Table 2

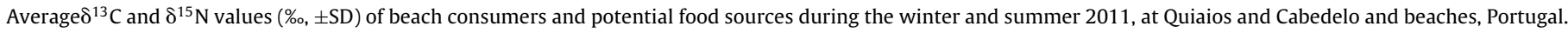

\begin{tabular}{|c|c|c|c|c|c|c|c|c|c|}
\hline & \multirow[t]{3}{*}{$n$} & \multicolumn{4}{|c|}{ Quiaios } & \multicolumn{4}{|c|}{ Cabedelo } \\
\hline & & \multicolumn{2}{|l|}{ Winter } & \multicolumn{2}{|l|}{ Summer } & \multicolumn{2}{|l|}{ Winter } & \multicolumn{2}{|l|}{ Summer } \\
\hline & & $\delta^{13} \mathrm{C}$ & $\delta^{15} \mathrm{~N}$ & $\delta^{13} \mathrm{C}$ & $\delta^{15} \mathrm{~N}$ & $\delta^{13} \mathrm{C}$ & $\delta^{15} \mathrm{~N}$ & $\delta^{13} \mathrm{C}$ & $\delta^{15} \mathrm{~N}$ \\
\hline \multicolumn{10}{|l|}{ Consumers } \\
\hline T. saltator & 6 & $-20.69(0.18)$ & $8.99(0.13)$ & $-18.67(0.18)$ & $9.58(0.27)$ & $-19.29(0.41)$ & $12.11(1.15)$ & $-18.02(0.38)$ & $11.86(0.39)$ \\
\hline T. brito & 6 & $-19.25(0.41)$ & $12.75(0.14)$ & $-18.56(0.54)$ & $11.36(0.29)$ & $-16.23(0.27)$ & $12.82(0.51)$ & $-16.53(0.39)$ & $12.57(0.48)$ \\
\hline $\begin{array}{l}\text { T. europaeus } \\
\text { Sources }\end{array}$ & 6 & $-16.81(0.23)$ & $11.73(0.65)$ & $-15.75(0.52)$ & $11.31(0.52)$ & $-19.31(0.21)$ & $12.53(0.44)$ & $-14.73(0.61)$ & $11.86(0.34)$ \\
\hline POM & 3 & $-16.59(0.18)$ & $7.16(0.24)$ & $-18.55(0.27)$ & $7.03(0.18)$ & $-17.89(0.46)$ & $6.43(0.38)$ & $-18.43(0.31)$ & $8.79(0.03)$ \\
\hline Dune plants & 3 & $-28.40(0.41)$ & $2.57(0.24)$ & $-26.14(0.21)$ & $2.66(1.24)$ & $-26.06(0.08)$ & $8.06(0.08)$ & $-28.17(0.24)$ & $4.48(0.68)$ \\
\hline Fucus sp. & 3 & $-20.05(0.03)$ & $8.54(0.02)$ & $-19.39(0.54)$ & $9.05(0.07)$ & $-17.67(0.11)$ & $10.78(0.97)$ & $-18.55(0.14)$ & $9.70(0.02)$ \\
\hline Ulva sp. & 3 & $-13.37(0.11)$ & $9.77(0.07)$ & $-14.29(0.21)$ & $14.06(0.07)$ & $-14.28(0.03)$ & $12.56(0.09)$ & $-16.35(0.04)$ & $12.78(0.21)$ \\
\hline Carrion & 3 & - & - & - & - & $-18.38(0.03)$ & $11.05(0.06)$ & $-19.06(0.93)$ & $9.05(0.03)$ \\
\hline
\end{tabular}



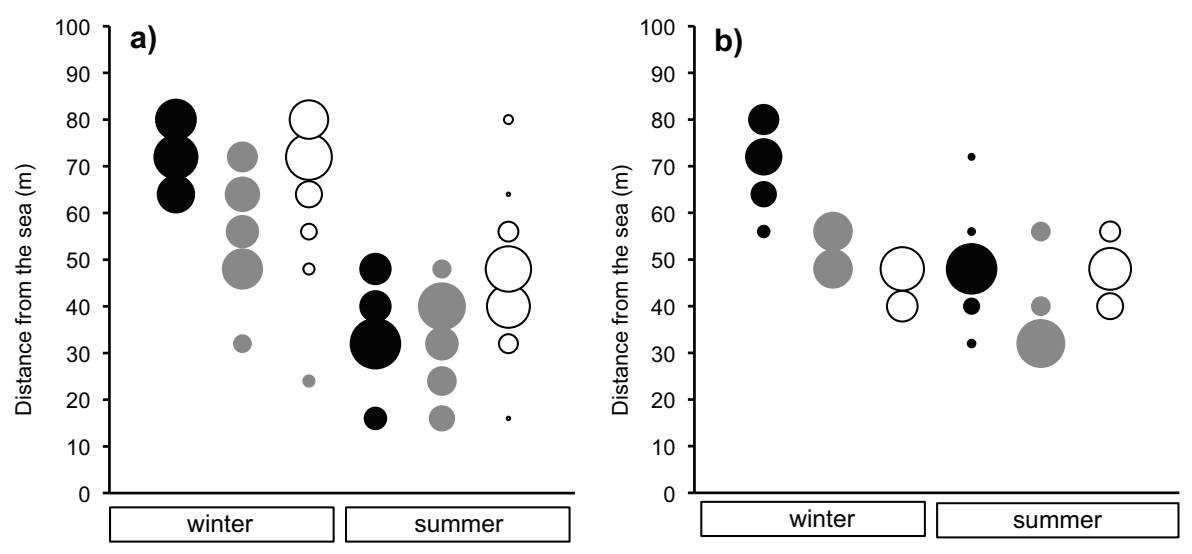

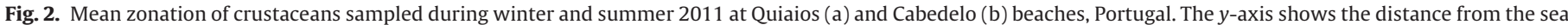
(m). Bubble size indicates the frequencies recorded of crustaceans. Black bubbles: Talitrus saltator; grey bubbles: Talorchestia brito and white bubbles: Tylos europaeus.

PERMANOVA: $p$ (perm) <0.05), suggesting differences in foraging behaviour between consumers (diet and/or feeding area). However, during summer, talitrids showed similar $\delta^{13} \mathrm{C}$ values ( $T$. saltator $=-18.67 \%$ and $T$. brito $=-18.67 \%$ ), and $T$. saltator exhibited relatively $\delta^{15} \mathrm{~N}$ depleted values compared to the other two species (Table 2).

In contrast, at Cabedelo, there was ample overlap in $\delta^{15} \mathrm{~N}$ values of consumers in winter $(p$ (perm) $>0.05)$, while in the summer, $T$. brito was significantly more $\delta^{15} \mathrm{~N}$ enriched than the other co-occurring crustaceans (Table 2; Fig. 3c and d). T. brito was also significantly more $\delta^{13} \mathrm{C}$ enriched in winter, and T. europaeus during summer (PERMANOVA: $p$ (perm) <0.05; Table 2).

\subsubsection{Food sources}

The dune plants signatures of $\delta^{13} \mathrm{C}$ and $\delta^{15} \mathrm{~N}$ were more depleted on average than the other food items at both beaches (Table 2 , Fig. 3).

b)
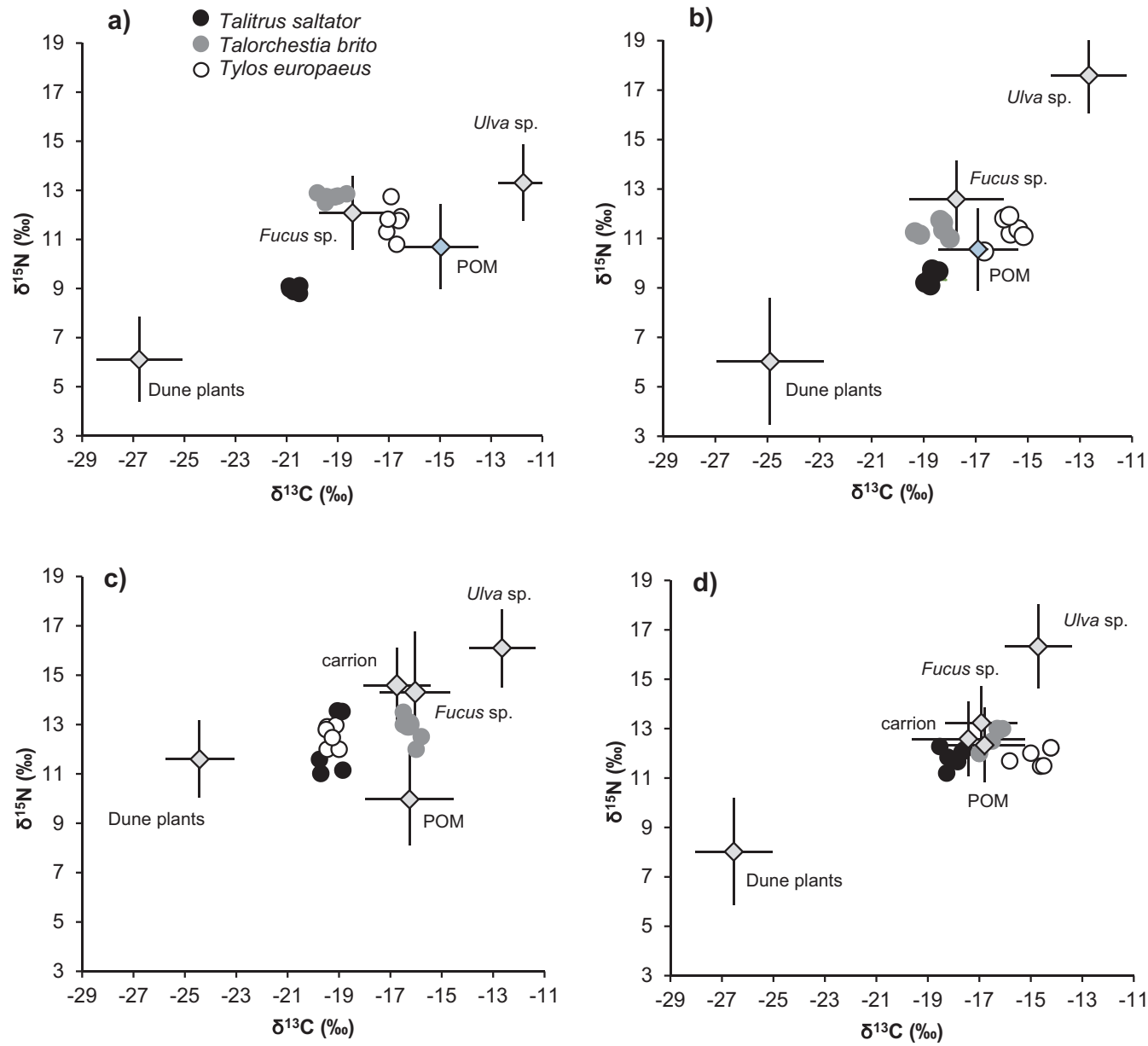

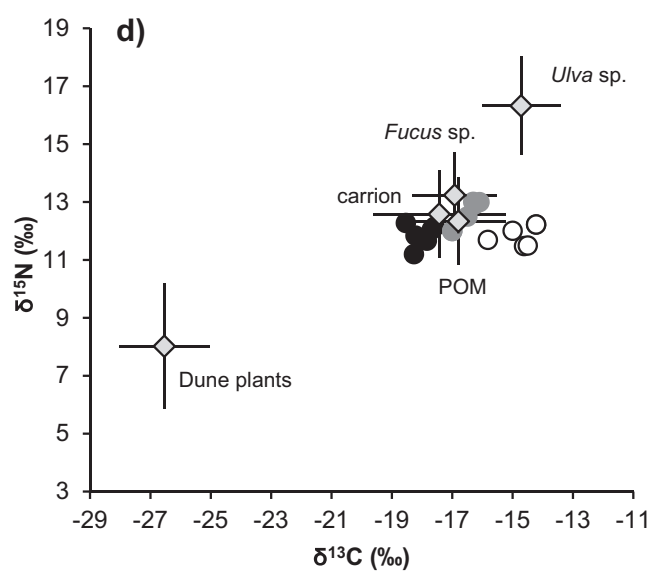

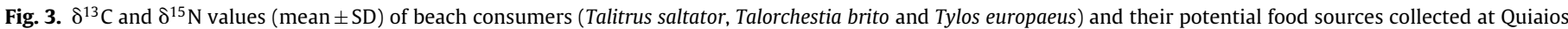

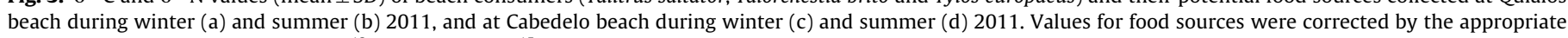
trophic fractionation values ( $1 \%$ for $\delta^{13} \mathrm{C}$ and $3.4 \%$ ofor $\delta^{15} \mathrm{~N}$ ). 
The $\delta^{13} \mathrm{C}$ and $\delta^{15} \mathrm{~N}$ values of all potential food sources showed significant differences between beaches in the same season (Tables 2 and 3: PERMANOVA all interaction terms: $p$ (perm) $<0.05$ ). The available food sources in Quiaios showed statistically temporal distinct isotopic signals ( $p(\mathrm{MC})<0.05$ ) except for the dune plants (Table 2; PERMANOVA: $p(\mathrm{MC})>0.05$ ). The isotopic ratios of all sources at Quiaios varied also significantly among them in both seasons $(p$ (perm) $>0.05)$, and ranged from -26.40 to $-13.37 \%$ 。 $\left(\delta^{13} \mathrm{C}\right)$, and from 2.66 to $14.06 \%$ ( $\left(\delta^{15} \mathrm{~N}\right.$; Table 2 ; Fig. $3 \mathrm{a}$ and $\mathrm{b}$ ).

The dominant food sources found in Cabedelo showed less segregation in the isotopic signatures in both seasons (Table 2, Fig. 3c and d). The $\delta^{13} \mathrm{C}$ values of POM, Fucus sp. and carrion showed seasonal stability (Table $2 ; p(\mathrm{MC})>0.05$ ), while $\delta^{15} \mathrm{~N}$ values of Fucus sp., Ulva sp. and carrion exhibited a slight variation (Table 2).

\subsection{Mixing model outputs}

Statistical comparisons between potential food resources contribution to the diet of consumers estimated by SIAR were performed for each beach and season (Figs. 4 and 5). Regarding the Quiaios beach, Bayesian mixing model outcomes showed a high variability in the relative contributions of the three major organic matter sources to the diet of consumers (Fig. 4). During winter, $T$. saltator selected mainly dune plants as food source with a mean contribution of $47 \%$ (Fig. 4a), with diet switching in the summer, with POMs contributing $75 \%$ to its diet (Fig. 4a). In contrast, SIAR results showed that the co-occurring talitrid $T$. brito, also during winter, relied mainly on the brown algae Fucus sp. as basal source (on average $41 \%$; mean $\min =5 \%$; mean $\max =84 \%$; Fig. $4 \mathrm{~b}$ ), with a mixed diet with similar contributions of sources in the summer (Fig. 4b). Fucus sp. showed also the highest mean relative contribution to the diet of T. europaues (40\%), followed by Ulva sp. (28\%) and POM (20\%) while dune plants represented a minor contribution in winter (Fig. 4c). By contrast, during summer, POM showed the highest contribution to the diet of T. europaeus (56\%), displaying proportion values from $21 \%$ to $87 \%$ (Fig. $4 \mathrm{c}$ ).

Our model for Cabedelo beach indicated that in general all food sources contributed to the diet of consumers, since no more than $40 \%$ of individual contributions were found in both seasons (Fig. 5). In winter, dune plants appeared the most important food source for $T$. saltator and T. europaeus ( $40 \%$ each), while $T$. brito seems to have a mixed diet composed mainly by POM (35\%) followed by similar proportions of Fucus sp. (20\%), Ulva sp. (19\%) and carrion (18\%) (Fig. 5b). In summer, Fucus sp. was the main food assimilated by $T$. brito (40\%) and T. europaeus (33\%), while T. saltator depended on similar proportions of carrion (26\%), Fucus sp. (25\%) and POM (24\%). Ulva sp. and dune plants provided minor contributions $(\approx 15 \%$ each) during the warmer season at Cabedelo (Fig. 5).

\section{Discussion}

The transfer of organic material from allochthonous sources to primary consumers varies widely among beaches with different morphodynamics (Bergamino et al., 2013), but little is known about the ecological feeding strategies of these consumers when dealing with environmental and/or physical fluctuations.

The use of stable isotope analysis and zonation patterns of primary consumers in this study revealed several important aspects of the foraging ecology of three sympatric crustaceans - the talitrid amphipods $T$. saltator, $T$. brito and the oniscoidean isopod $T$. europaeus - from two sandy beaches with contrasting wrack availabilities.

Both beaches are highly dynamic and subject to similar environmental conditions, since they are relatively close to each other $(8 \mathrm{~km}$ apart, Fig. 1$)$. The main differences between these mesotidal
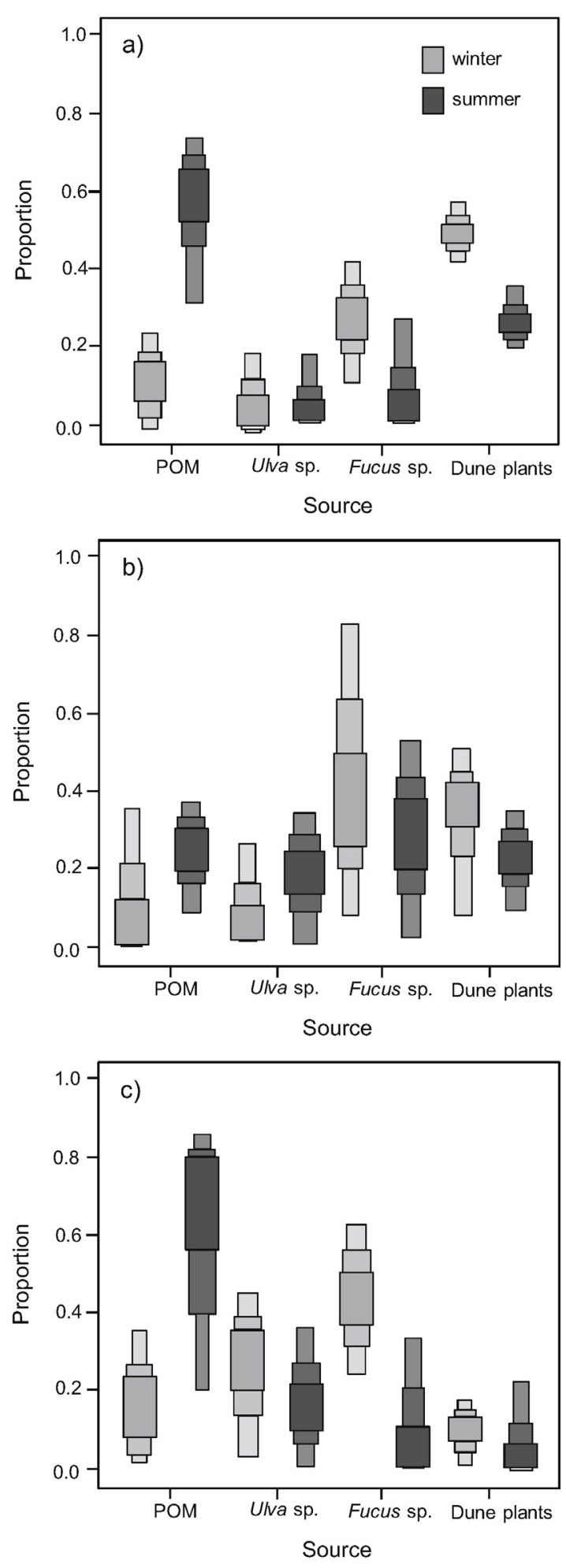

Fig. 4. Results of SIAR ( 95,75 and $25 \%$ credibility intervals) for Quiaios beach showing estimated food sources contribution to (a) Talitrus saltator, (b) Talorchestia brito, and (c) Tylos europaeus diets during both winter (light boxes) and summer (dark boxes) 2011.

beaches are related with the allochthonous inputs from the sea. The highest deposits of wrack species (Fucus sp., Ulva sp., carrion) were recorded mainly on the drift line of Cabedelo, whereas at Quiaios, the major allochthonous source arrived in the form of phytoplankton (Table 1). Gonçalves and Marques (2011) highlighted the clear 

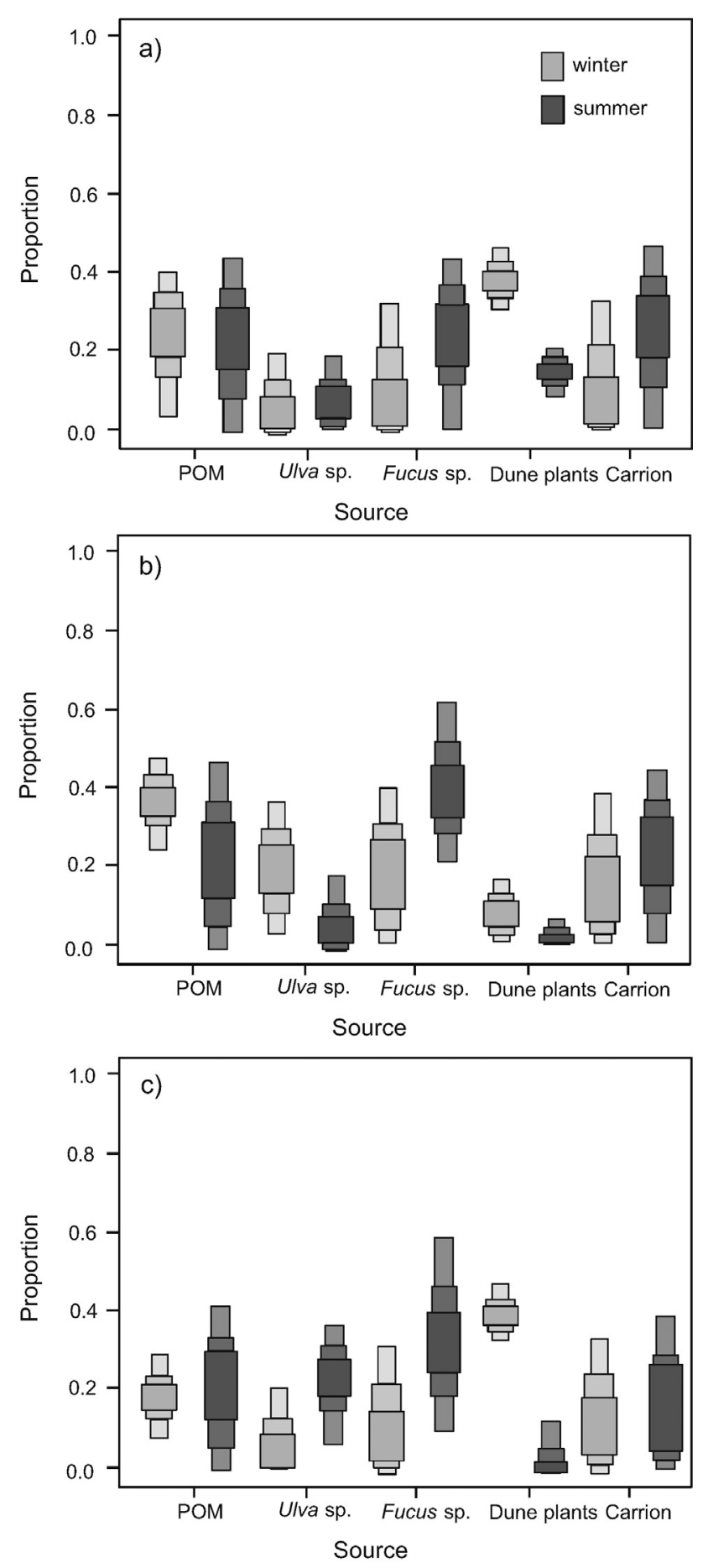

Fig. 5. Results of SIAR (95\%, $75 \%$ and $25 \%$ credibility intervals) for Cabedelo beach showing estimated food sources contribution to (a) Talitrus saltator, (b) Talorchestia brito, and (c) Tylos europaeus diets during both winter (light boxes) and summer (dark boxes) 2011.

dependence of macrofauna of these beaches on the wrack subsidies, namely their positive influence on the density.

The stable isotopic analysis revealed significant differences in both carbon and nitrogen values of primary consumers and the potential food sources between beaches. In particular, the isotopic signals of all sympatric crustaceans were significantly higher in Cabedelo beach as compared to Quiaios. The higher $\delta^{15} \mathrm{~N}$ signatures seen in the consumers living in Cabedelo, which is adjacent to the Mondego estuary, can be related to the available nitrogen released from the river mouth to the coastal area. Nitrogen values of marine consumers are thought to reflect nutrient enriched zones, such as estuaries, and several studies have linked nutrient loadings with high biotic $\delta^{15} \mathrm{~N}$ (Vander Zanden et al., 2005).

As inputs of distinct food sources may be seasonally variable, isotopic signatures of primary consumers associated with those sources are known to present also seasonal variations (Bergamino et al., 2011; Rossi et al., 2010). Our study has shown a striking temporal difference in carbon and nitrogen isotopes among all consumers for the beach with low accumulations of wrack.

At Quiaios beach, during winter (Fig. 3a), the significant differences found in the isotopic signatures of both primary consumers and food sources might suggest different foraging areas for these crustaceans. Since arrival of macrophyte material is stochastic at best in Quiaios, and presents seasonal and spatial fluctuations, this variability is likely to affect the diet of consumers and the need to forage on different available sources for its requirements. Here, the amphipod $T$. saltator had the most terrestrial isotopic signal with lower $\delta^{13} \mathrm{C}$ signatures, i.e. signatures closer to those dune plants, while $T$. brito and $T$. europaeus signatures were closed to the allochthonous resources (Fucus sp. and POM). This pattern was clearly consistent with the zonation observed during the coolest season, when $T$. saltator was exclusively found in the supralittoral zone, and the other two-occurring species showed a lower position on the beach (Fig. 2a). This suggests some spatial segregation along sea-dune axis, with $T$. saltator foraging higher on the beach and hence, closer to the foredunes. Moreover, SIAR outputs were in accordance with the position occupied by the sympatric crustaceans in winter in this beach. Dune plants were the main contributor to diet of T. saltator (47\%) and Fucus sp. the main contributor to the other two species diets (about 40\%). Consequently, the ecological niche of these species might differ during winter, with a spatial partitioning allowing the coexistence of beach primary consumers at Quiaios. In this situation, a shortage in wrack detritus availability seems to promote a supralittoral foraging area for $T$. saltator offering additional potential food resources (such as dune plant detritus).

The behavioural plasticity of $T$. saltator has been widely recognised, as a species capable to move across the shoreline in order to maintain an optimal position on the beach (Scapini et al., 1997). In addition, this species is considered to be an opportunistic feeder and a poor swimmer, thus in order to avoid the risk of being swept in this dynamic beach during spring tides, this species can adopt the strategy of remaining at the base of the foredunes where can find also a safe refuge.

In contrast, the isotopic signatures of consumers varied markedly in summer suggesting a temporal change in the foraging area, with crustaceans occurring mainly in the lower zone of the beach, as close as $10 \mathrm{~m}$ from the sea in the case of $T$. brito and $T$. europaeus (Fig. 2a). The SIAR results provided evidence of the temporary diet switching, in the case of $T$. saltator from dune plants detritus in winter to POM-dominated diet in summer. A relatively similar trend was also observed for T. europaeus and, although to a less extent, for T. brito (Fig. 4). Diet switching clearly indicates an opportunistic foraging strategy in which a consumer may change its diet to take advantage of temporary available food resource or to replace a preferred resource that has become unavailable. Here, both patterns emerged, since these species (especially during the summer), needed to find a moist sand stripe along the shoreline to avoid desiccation, and a food resource available, in this case represented by higher phytoplankton concentrations (Table 1 ). The coastal foraging habitat preferences showed by these species are confirmed by their higher $\delta^{13} \mathrm{C}$ values in summer as compared to winter, which indicates a benthic carbon source that is primarily available in the intertidal zone of the beach. The habitat available in this beach favoured the distribution of sympatric species along 
the shoreline, but with a different vertical position depending on the season and resources availability.

Our results are in accordance with those described by Lastra et al. (2010), which found clear differences in the surface activity in the same species analysed here, with evident niche differentiation along the spatial axis. These authors also highlighted the lower position on the beach for $T$. brito, a pattern also recorded in our study in both beaches. To this regard, the estimation of stable isotopes of $T$. brito (specifically nitrogen values) was very similar between beaches and seasons (Table 2), which is also illustrated by the main contribution of the same single food type (mainly Fucus sp.) to its diet. Our results emphasize therefore the intertidal affinity and limited foraging habitat of this amphipod species, which was also recognised by Fallaci et al. (1999).

Contrasting to Quiaios, the same sympatric primary consumers showed at Cabedelo identical mean $\delta^{15} \mathrm{~N}$ values during the winter, which suggests substantially similar trophic niches. The little variation in $\delta^{13} \mathrm{C}$ values found between $T$. saltator and T. europaeus (Table 1) indicates that these species might consume the same food resources. Actually, SIAR results reflected this prediction, dune plants appearing as the main contributor to the diet of $T$. saltator (39\%) and T. europaeus (40\%), while nearshore POM represents the main food source to $T$. brito (mean $35 \%$ ). The vertical pattern of distribution also revealed a higher position of $T$. saltator on the shore, whereas the other two occurring species where found closer to the drift line. Therefore, at Cabedelo, some spatial segregation seems to occur amongst crustaceans, although in a less extent as compared to Quiaios.

During summer, consumers exhibited a relatively narrow range of $\delta^{13} \mathrm{C}$ and $\delta^{15} \mathrm{~N}$ signatures, which indicates similar and rather narrow niches (Fig. 3b). This interpretation is reinforced by the overlap in summer zonation of these species in the drift line. Mixing models revealed that these consumers feed on mix food resources since any item contributed more than $40 \%$ to its diets (Fig. 5). Nevertheless, the similar contributions of POM, Fucus sp. and carrion (about 20\% each) suggest an opportunistic and generalistic feeding behaviour of these species at Cabedelo.

Previous studies with amphipods (and T. saltator) consuming wrack have reported feeding preferences for macroalgae over other food items (e.g. Adin and Riera, 2003; Crawley and Hyndes, 2007; Duarte et al., 2010; Poore and Gallagher, 2012), however, Rossi et al. (2010) described an opportunistic behaviour for amphipods that relied on seagrasses (Sargassum muticum) when this resource was deposited in large quantities on the shore, and Porri et al. (2011) found an ephemeral relationship between amphipods and specific wrack subsidies in South Africa. Herein, we also describe an opportunistic feeding behaviour, mainly of the consumers at Cabedelo beach, which might utilise the various sources indiscriminately as a result of the higher availability of wrack deposited on the shore. Such small-scale differences in food accessibility allow consumers to forage on the same location without the need to move across the beach, a pattern also consistent with the concentration of animals observed near the wrack deposits. Furthermore, these results agree with the hypothesis reported by Gonçalves and Marques (2011) that there might be considerable overlap between T. europaeus and T. saltator foraging areas in this beach.

An important feeding aspect emerged also from our results, which illustrated that the green algae Ulva sp. had minor contribution to the diet of consumers at both beaches, where it is only occasionally found (personal observations). This is consistent with previous studies reporting that supratidal invertebrates had little effects on the decomposition of Ulva sp. (Catenazzi and Donnelly, 2007), as well as with the findings of Adin and Riera (2003) and Olabarria et al. (2009), which claimed that Ulva was the less preferential food source for the sandhopper T. saltator.
Overall, instead of elucidating unambiguously interspecific differences in diets, our results provide evidence of the influence of wrack availability on the foraging strategy of primary consumers, and illustrate how temporal fluctuations may affect niche segregation.

The spatial winter niche differentiation found at Quiaios clearly shows how sympatric crustaceans in this beach are distributed along the marine-terrestrial gradient to avoid physiological stress on this beach and potential interspecific competition. Given the level of resource partitioning observed in winter in both beaches, although to a less extent at Cabedelo, it is likely that these crustaceans have adopted specific feeding strategies to maintain an optimal position along the shore. Such strategies may function to reduce interspecific competition allowing congeneric species to successfully co-occur in similar systems (Huxel et al., 2002). On the other hand, at Cabedelo beach, where wrack subsidies are abundant, crustaceans were able to be more concentrated on the drift line, exhibiting opportunistic and generalist feeding behaviour, and consequently an overlap in the foraging habitat.

Our study illustrates the viability of using stable isotopes to capture subtle changes in trophic niches, in this case seasonal and corresponding to winter foraging individual specialisation in beach primary consumers. Even generalist species in poor-environments can cohabit exhibiting different spatial and temporal feeding strategies, and our findings agree with Rodríguez and Herrera (2012) paradigm that isotopic niche might mirrors trophic niche of sympatric species with similar feeding diets. The food partitioning may allow the coexistence of interacting species and provides evidence that biological interactions are indeed important in the community structure of sandy beach macrofauna.

\section{Acknowledgements}

This research was supported by FCT (Fundação para a Ciência e Tecnologia) in the scope of the Project PEst-C/MAR/UI0284/2011 and through a PhD Grant awarded to Ana Filipa Bessa (SFRH/BD/64929/2009). We wish to give our special thanks to all who assisted us in the fieldwork.

\section{References}

Adin, R., Riera, P., 2003. Preferential food source utilization among stranded macroalgae by Talitrus saltator (Amphipod Talitridae): a stable isotopes study in the northern coast of Brittany (France). Estuarine Coastal Shelf Sci. 56, 91-98.

Anderson, M.J., 2001. A new method for non-parametric multivariate analysis of variance. Austral Ecol. 26, 32-46.

Baeta, A., Pinto, R., Valiela, I., Richard, P., Niquil, N., Marques, J.C., 2009. $\delta^{15} \mathrm{~N}$ and $\delta^{13} \mathrm{C}$ in the Mondego estuary food web: seasonal variation in producers and consumers. Mar. Environ. Res. 67, 109-116.

Bergamino, L., Gomez, J., Barboza, F.R., Lercari, D., 2013. Major food web properties of two sandy beaches with contrasting morphodynamics, and effects on the stability. Aquat. Ecol., http://dx.doi.org/10.1007/s10452-013-9440-5.

Bergamino, L., Lercari, D., Defeo, O., 2011. Food web structure of sandy beaches: temporal and spatial variation using stable isotope analysis. Estuarine Coastal Shelf Sci. 91, 536-543.

Boecklen, W.J., Yarnes, C.T., Cook, B.A., James, A.C., 2011. On the use of stable isotopes in trophic ecology. Annu. Rev. Ecol. Evol. Syst. 42, 411-440.

Catenazzi, A., Donnelly, M.A., 2007. Role of supratidal invertebrates in the decomposition of beach-cast green algae Ulva sp. Mar. Ecol. Prog. Ser. 349, 33-42.

Colombini, I., Aloia, A., Fallaci, M., Pezzoli, G., Chelazzi, L., 2000. Temporal and spatial use of stranded wrack by the macrofauna of a tropical sandy beach. Mar. Biol. 136, 531-541

Colombini, I., Brilli, M., Fallaci, M., Gagnarli, E., Chelazzi, L., 2011. Food webs of a sandy beach macroinvertebrate community using stable isotopes analysis. Acta Oecol. 37, 422-432.

Colombini, I., Chelazzi, L., Gibson, R.N., Atkinson, R., 2003. Influence of marine allochthonous input on sandy beach communities. Oceanogr. Mar. Biol. Annu. Rev. 41, 115-159.

Colombini, I., Mateo, M.A., Serrano, O., Fallaci, M., Gagnarli, E., Serrano, L., Chelazzi, L., 2009. On the role of Posidonia oceanica beach wrack for macroinvertebrates of a Tyrrhenian sandy shore. Acta Oecol. 35, 32-44. 
Crawley, K.R., Hyndes, G.A., 2007. The role of different types of detached macrophytes in the food and habitat choice of a surf-zone inhabiting amphipod. Mar. Biol. 151, 1433-1443.

Crawley, K.R., Hyndes, G.A., Vanderklift, M.A., Revill, A.T., Nichols, P.D., 2009. Allochthonous brown algae are the primary food source for consumers in a temperate, coastal environment. Mar. Ecol. Prog. Ser. 376, 33-44.

Cummings, D.O., Buhl, J., Lee, R.W., Simpson, S.J., Holmes, S.P., 2012. Estimating niche width using stable isotopes in the face of habitat variability: a modelling case study in the marine environment. PLoS One 7, e40539.

Danielsen, R., 2008. Palaeoecologial development of the Quiaios-Mira dunes, northern-central littoral Portugal. Rev. Palaeobot. Palynol. 152, 74-99.

DeNiro, M., Epstein, S., 1978. Influence of diet on the distribution of carbon isotopes in animals. Geochim. Cosmochim. Acta 42, 495-506.

DeNiro, M., Epstein, S., 1980. Influence of diet on the distribution of nitrogen isotopes in animals. Geochim. Cosmochim. Acta 45, 341-351.

Duarte, C., Navarro, J.M., Acuña, K., Gómez, I., 2010. Feeding preferences of the sandhopper Orchestoidea tuberculata: the importance of algal traits. Hydrobiologia 651, 291-303.

Dugan, J.E., Hubbard, D.M., McCrary, M.D., Pierson, M.O., 2003. The response of macrofauna communities and shorebirds to macrophyte wrack subsidies on exposed sandy beaches of southern California. Estuarine Coastal Shelf Sci. 58, 25-40.

Duong, H.L.S., Fairweather, P.G., 2010. Effects of sandy beach cusps on wrack accumulation, sediment characteristics and macrofaunal assemblages. Austral Ecol. 5, 429-436.

Fallaci, M., Aloia, A., Audoglio, M., Colombini, I., Scapini, F., Chelazzi, L., 1999. Differences in behavioural strategies between two sympatric talitrids (Amphipoda) inhabiting an exposed sandy beach of the French Atlantic coast. Estuarine Coastal Shelf Sci. 48, 469-482.

Gómez, M., Barreiro, F., López, J., Lastra, M., la Huz de, R., 2013. Deposition patterns of algal wrack species on estuarine beaches. Aquat. Bot. 105, 25-33.

Gonçalves, S.C., Anastácio, P.M., Marques, J.C., 2013. Talitrid and tylid crustaceans' bioecology as a tool to monitor and assess sandy beaches' ecological quality condition. Ecol. Ind. 29, 549-557.

Gonçalves, S.C., Anastácio, P.M., Pardal, M.A., Cardoso, P.G., Ferreira, S.M., Marques, J.C., 2009. Sandy beach macrofaunal communities on the western coast of Portugal-is there a steady structure under similar exposed conditions? Estuarine Coastal Shelf Sci. 81, 555-568.

Gonçalves, S.C., Marques, J.C., 2011. The effects of season and wrack subsidy on the community functioning of exposed sandy beaches. Estuarine Coastal Shelf Sci. 95, 165-177.

Gonçalves, S.C., Pardal, M.A., Cardoso, P.G., Ferreira, S.M., Marques, J.C., 2005. Biology, population dynamics and secondary production of Tylos europaeus (Isopoda, Tylidae) on the western coast of Portugal. Mar. Biol. 147, 631-641.

Griffiths, C.L., Stenton-Dozey, J.M.E., Koop, K., 1983. Kelp wrack and the flow of energy through a sandy beach ecosystem. In: McLachlan, A., Erasmus, T. (Eds.), Proceedings of the First International Symposium on Sandy Beaches, Port Elizabeth, South Africa, 17-21 January 1983. Sandy Beaches as Ecosystems, The Hague, Jungk, pp. 547-556.

Heck Jr., K.L., Carruthers, T.J.B., Duarte, C.M., Hughes, A.R., Kendrick, G., Orth, R.J., Williams, S.W., 2008. Trophic transfers from seagrass meadows subsidize diverse marine and terrestrial consumers. Ecosystems 11, 1198-1210.

Huxel, G.R., McCann, K., Polis, G.A., 2002. Effects of partitioning allochthonous and autochthonous resources on food web stability. Ecol. Res. 17, 419-432.

Hyndes, G.A., Lavery, P.S., 2005. Does transported seagrass provide an important trophic link in unvegetated, nearshore areas? Estuarine Coastal Shelf Sci. 63, 633-643.

Ince, R., Hyndes, G.A., Lavery, P.S., Vanderklift, M.A., 2007. Marine macrophytes directly enhance abundances of sandy beach fauna through provision of food and habitat. Estuarine Coastal Shelf Sci. 74, 77-86.

Jaramillo, E., Contreras, H., Duarte, C., Avellanal, M.H., 2003. Locomotor activity and zonation of upper shore arthropods in a sandy beach of north central Chile. Estuarine Coastal Shelf Sci. 58, 177-197.

Jaramillo, E., La Huz, de, R., Duarte, C., Contreras, H., 2006. Algal wrack deposits and macroinfaunal arthropods on sandy beaches of the Chilean coast. Rev. Chil. Hist. Nat. 79, 337-351.

Lastra, M., Page, H.M., Dugan, J.E., Hubbard, D.M., Rodil, I.F., 2008. Processing of allochthonous macrophyte subsidies by sandy beach consumers: estimates of feeding rates and impacts on food resources. Mar. Biol. 154, 163-174.
Lastra, M., Schlacher, T.A., Olabarria, C., 2010. Niche segregation in sandy beach animals: an analysis with surface-active peracarid crustaceans on the Atlantic coast of Spain. Mar. Biol. 157, 613-625.

MacMillan, M.R., Quijón, P.A., 2012. Wrack patches and their influence on uppershore macrofaunal abundance in an Atlantic Canada sandy beach system. J. Sea Res. 72, 28-37.

Marques, J.C., Gonçalves, S.C., Pardal, M.A., Chelazzi, L., Colombini, I., Fallaci, M., Bouslama, M.F., El Gtari, M., Charfi-Cheikhrouha, F., Scapini, F., 2003. Comparison of Talitrus saltator (Amphipoda Talitridae) biology, dynamics, and secondary production in Atlantic (Portugal) and Mediterranean (Italy and Tunisia) populations. Estuarine Coastal Shelf Sci. 58, 127-148.

McLachlan, A., Brown, A.C., 2006. The Ecology of Sandy Shores, second ed. Academic Press, New York.

McLeod, R.J., Hyndes, G.A., Hurd, C.L., Frew, R.D., 2013. Unexpected shifts in fatty acid composition in response to diet in a common littoral amphipod. Mar. Ecol. Prog. Ser. 479, 1-12.

Minagawa, M., Wada, E., 1984. Stepwise enrichment of $\delta^{15} \mathrm{~N}$ along foodchains-further evidence and the relation between $\delta^{15} \mathrm{~N}$ and animal age. Geochim. Cosmochim. Acta 48, 1135-1140.

Olabarria, C., Incera, M., Garrido, J., Rodil, I.F., Rossi, F., 2009. Intraspecific diet shift in Talitrus saltator inhabiting exposed sandy beaches. Estuarine Coastal Shelf Sci. $84,282-288$

Olabarria, C., Lastra, M., Garrido, J., 2007. Succession of macrofauna on macroalga wrack of an exposed sandy beach: effects of patch size and site. Mar. Environ. Res. 63, 19-40.

Orr, M., Zimmer, M., Jelinski, D.E., Mews, M., 2005. Wrack deposition on different beach types: spatial and temporal variation in the pattern of subsidy. Ecology 86, 1496-1507.

Parnell, A.C., Inger, R., Bearhop, S., Jackson, A.L., 2010. Source portioning using stable isotopes: coping with too much variation. PLoS One 5, 3.

Peterson, B.J., Fry, B., 1987. Stable isotopes in ecosystem studies. Annu. Rev. Ecol. Syst. $18,293-320$.

Polis, G.A., Anderson, W.B., Holt, R.D., 1997. Toward an integration of landscape and food web ecology: the dynamics of spatially subsidized food webs. Annu. Rev. Ecol. Syst. 28, 289-316.

Poore, A.G.B., Gallagher, K.M., 2012. Strong consequences of diet choice in a talitrid amphipod consuming seagrass and algal wrack. Hydrobiologia 701, 117-127.

Porri, F., Hill, J.M., McQuaid, C.D., 2011. Associations in ephemeral systems: the lack of trophic relationships between sandhoppers and beach wrack. Mar. Ecol. Prog. Ser. 426, 253-262.

Post, D.M., 2002. Using stable isotopes to estimate trophic position: models, methods, and assumptions. Ecology 83, 703-718.

Rodil, I.F., Olabarria, C., Lastra, M., López, J., 2008. Differential effects of native and invasive algal wrack on macrofaunal assemblages inhabiting exposed sandy beaches. J. Exp. Mar. Biol. Ecol. 358, 1-13.

Rodríguez, M.M.A., Herrera, M.L.G., 2012. Isotopic niche mirrors trophic niche in a vertebrate island invader. Oecologia 171, 537-544.

Rossi, F., Olabarria, C., Incera, M., Garrido, J., 2010. The trophic significance of the invasive seaweed Sargassum muticum in sandy beaches. J. Sea Res. 63, 52-61.

Rossi, F., Underwood, A.J., 2002. Small-scale disturbance and increased nutrients as influences on intertidal macrobenthic assemblages, experimental burial of wrack in different intertidal environments. Mar. Ecol. Prog. Ser. 241, 29-39.

Salathé, R., Riera, P., 2012. The role of Talitrus saltator in the decomposition of seaweed wrack on sandy beaches in northern Brittany: an experimental mesocosm approach. Cah. Biol. Mar. 53, 517-524.

Scapini, F., Audoglio, M., Chelazzi, L., Colombini, I., Fallaci, M., 1997. Astronomical, landscape and climatic factors influencing oriented movements of Talitrus saltator in nature. Mar. Biol. 128, 63-72.

Scapini, F., Chelazzi, L., Colombini, I., Fallaci, M., 1992. Surface activity, zonation and migrations of Talitrus saltator on a Mediterranean beach. Mar. Biol. 112, 573-581.

Vander Zanden, M.J., Rasmussen, J.B., 2001. Variation in d15 N and d13 C trophic fractionation: implications for aquatic food web studies. Limnol. Oceanogr. 48 , 2061-2066.

Vander Zanden, M.J., Vadeboncoeur, Y., Diebel, M.W., Jeppesen, E., 2005. Primary consumer stable nitrogen isotopes as indicators of nutrient source. Environ. Sci. Technol., 39. 